\title{
The Effects of Self Reminder Card to the Successful Treatment of Blood Pressure of Hypertension Patients in Community Health Centers in Surabaya
}

\author{
Selly Septi Fandinata*, Iin Ernawati \\ Akademi Farmasi Surabaya, Indonesia \\ *sellyfandinata@akfarsurabaya.ac.id
}

\begin{abstract}
Hypertension is a disease with high prevalence. Hypertension treatment aims to control blood pressure and prevent complications. Adherence to achieve the succesful treatment in hypertension patients can be improved by providing interventions with assistive tools from pharmaceutical services. Self-reminder card is a tool that can help patients to avoid forget in taking the medicine. The purpose of this study was to determine the effects of giving self-reminder cards on the successful treatment of blood pressure in hypertension patients at community health centers (puskesmas) in Surabaya. The research design was Quasi Experimental two groups (control and self-reminder card group) pre post prospective. The sample in this study was 115 patients divided into 2 groups, namely control group (55 patients) and intervention group (60 patients). The results showed that the successful of the systolic blood pressure of the patients pre and post the intervention group Wilcoxon test ( $p$ value 0.009 ) and the Mann Whitney test of both groups ( $\mathrm{p}$ value 0.009 ) so that there was an effect of the self-reminder card on the successful treatment in reducing systolic blood pressure of hypertension patients. In the pre and post diastolic blood pressure of the intervention group, the Wilcoxon test ( $\mathrm{p}$ value 0.016) and the Mann Whitney test was conducted for both groups ( $\mathrm{p}$ value 0.935 ) so that there was no effect of the self-reminder card on the successful treatment in reducing diastolic blood pressure in hypertension patients.
\end{abstract}

Keywords : Self-Reminder Card, Hypertension, Blood Pressure

Received August 1, 2020; Revised August 24, 2020; Accepted September 7, 2020 


\section{STRADA Jurnal Ilmiah Kesehatan}

DOI: $10.30994 /$ sjik.v9i2.395

ISSN: 2252-3847 (print); 2614-350X (online)

Vol.9 No.2 November 2020 Page.831-839

\section{BACKGROUND}

Hypertension sufferers tend to not realize that they get high blood pressure. Hence, this disease is categorized into one of the silent killers(1). High blood pressure (hypertension) is a big problem, not only in western countries but also in Indonesia. In Indonesia, the number of hypertension sufferers is estimated reaching 15 million sufferers but only $4 \%$ of them are controlled hypertension (2). According to the World Health Organization (WHO) 2011, hypertension causes nearly 8 million deaths every year. Nearly 1.5 million are residents of the Southeast Asian region. It is estimated that 1 in 3 adults in Southeast Asia are hypertension sufferers (3). The world health statistics reported that hypertension is a high-risk condition that causes approximately $51 \%$ of deaths from stroke and $45 \%$ of coronary heart disease. This condition becomes public health challenge because of the high morbidity and mortality rates.(4)

The goal of the treatment for people with hypertension is to improve quality of life. However, many hypertension patients stop the treatment when they feel their body getting well. Hence, it is necessary to get the patients adhere to hypertension treatment in order to obtain a better quality of life.(5) Considerable efforts are required to improve patient adherence to drug therapy in order to achieve the targeted blood pressure. The important things determine the successful of hypertension treatment are understanding, knowledge, and patient adherence. A study found that patients who discontinued antihypertensive therapy were five times more possible to get stroke (6). Based on a report by the World Health Organization (WHO) in 2003, the average adherence of patients of long-term therapy for chronic diseases was $50 \%$ in developed countries, and it was estimated to be lower in developing countries (3).

Adherence in taking medication for hypertension patients is very important because taking antihypertensive drugs regularly is able to control the blood pressure of hypertension sufferers. Therefore, in the long term, the risk of damage to important organs of the body such as the heart, kidneys and brain can be reduced. In this case, increased understanding of treatment instructions and increased patient adherence are strongly influenced by interventions of pharmaceutical care (7) (8). In this case, the role of pharmacists is needed in providing pharmaceutical services by giving intervention to patients in order to increase adherence so that the successful of patient therapy can be achieved (9).

One of interventions given by pharmacist that is able to improve patient's adherence is using self-reminder card. Self-reminder card is a tool helping patients to avoid forget taking the medicine by marking the column available on the medication reminder chart after taking the medicine (10)(11)(12). Self-reminder card is the development of a selfservice reminder card of taking medication on guidelines of pharmacy services counseling in health facilities (Pedoman Konseling Pelayanan Kefarmasian di Sarana Kesehatan) issued by the Indonesian Ministry of Health in 2017 and other similar researches. Development of self-reminder card in this research equipped with tools in the form of the picture of rules for taking medicine which is expected to improve the patient's understanding of the schedule of drug taking. Self-reminder card is designed by researchers as the identity of patient treatment that is easy to be carried out when traveling, because it contains a history of the patient's treatment, so it helps the doctor in prescribing treatment for the patient (13)

Puskesmas (community health center) is a first level health facility so it is a key promotion and preventive programs in supporting the successful of patients' therapeutic treatment. Surabaya has 61 community health centers spread in several regions, so that 


\section{STRADA Jurnal Ilmiah Kesehatan}

DOI: $10.30994 /$ sjik.v9i2.395

ISSN: 2252-3847 (print); 2614-350X (online)

Vol.9 No.2 November 2020 Page.831-839

community health centers in Surabaya also plays important role. Therefore, it is necessary to conduct a research to know whether the self-reminder card has an effect on the successful treatment of blood pressure in hypertension patients at community health centers in Surabaya or not. The results of this research are expected to be a reference to support the pharmacy services conducted in Community Health Centers (Puskesmas) and also the development of science in pharmacy field, especially to improve pharmaceutical services for hypertension patients.

\section{RESEARCH METHODS}

This study used pre post Quasi Experimental two groups (control and self-reminder card groups) designs by taking prospective primary and secondary patient data. The data observed were the successful of blood pressure in hypertension patients. The research was conducted at 10 health centers in Surabaya from April until June 2020.

Primary data were obtained from patient medical records (patient blood pressure) and other secondary data obtained from patient medical records and patient medication records.

The sample selection in this study used the purposive sampling method that was taken from control and intervention groups. Control and intervention groups consisted of all patients diagnosed hypertension and got antihypertensive drug therapy which was in accordance with the research criteria, namely:

Inclusion Criteria

1. Patients (aged 20-80 years) diagnosed hypertension without comorbidity which got anti-hypertensive drug therapy.

2. Patients which had complete data (medical record and prescription medications).

3. Patients visited community health center at least 2 visits.

4. Patients who were willing to be contacted via WA (what app)

Exclusion criteria

1. Children

2. Incomplete patient medical record data

3. Pregnant patients

Drop Out Criteria

1. Patients who had included into inclusion criteria but dropped out at a predetermined time

2. Patients who had included into inclusion criteria that changed the drug therapy regimen

Data on the successful of patient therapy in the form of pre patient blood pressure was measured when the patient came to the community health centers and the patient's blood pressure was re-measured again after 2 weeks. Data on the successful of this therapy was carried out in the control group (without giving self-reminder card) and intervention group (by giving self-reminder card).

Statistical analysis in this study was to determine the effects of the self-reminder card on the successful treatment of hypertension patients' blood pressure, which was analyzed in pairs if the resulting data were not normally distributed; it was tested using the independent two-sample t-test (Wilcoxon). While if the data were unpaired (independent) and it was not normally distributed, it was analyzed with two independent sample t-tests (Mann-Whitney). 


\section{RESULTS}

\section{Research Sample Characteristics}

The sample data on this study was 115 patients by considering inclusion and exclusion research criteria, which were divided into 2, namely control groups (55 patients) and interventions (60 patients) that given self-reminder card. The data presented in table 1.

Table 1. Characteristics of Patient Data in the Self Reminder Card and Control Groups

\begin{tabular}{|c|c|c|c|c|c|}
\hline \multirow{3}{*}{\multicolumn{2}{|c|}{ Patient characteristics }} & \multicolumn{4}{|c|}{ Group } \\
\hline & & \multicolumn{2}{|c|}{ Control $(\mathrm{N}=55)$} & \multicolumn{2}{|c|}{$\begin{array}{c}\text { Intervention }(\mathrm{N}= \\
60)\end{array}$} \\
\hline & & $\mathbf{N}$ & $\%$ & $\mathbf{N}$ & $\%$ \\
\hline \multirow[t]{2}{*}{ Gender } & Women & 43 & 78 & 49 & 82 \\
\hline & Man & 12 & 22 & 11 & 18 \\
\hline \multirow{5}{*}{ Age (years) } & $30-39$ & 2 & 3.64 & 3 & 5 \\
\hline & $40-49$ & 14 & 25.45 & 8 & 13.30 \\
\hline & $50-59$ & 15 & 27.27 & 25 & 41.70 \\
\hline & $60-69$ & 18 & 32.73 & 14 & 23.30 \\
\hline & $>70$ & 6 & 10.91 & 10 & 16.70 \\
\hline \multirow[t]{6}{*}{ Education } & No School & 0 & 0 & 1 & 2 \\
\hline & Elementary School & 11 & 20 & 31 & 51 \\
\hline & Junior high school & 14 & 25.45 & 16 & 27 \\
\hline & Senior High School & 22 & 40 & 11 & 18 \\
\hline & Diploma & 1 & 1.82 & 0 & 0 \\
\hline & Bachelor & 7 & 12.73 & 1 & 2 \\
\hline \multirow[t]{8}{*}{ Occupations } & Not working & 3 & 5.45 & 6 & 10 \\
\hline & Housewife & 36 & 65.45 & 29 & 48 \\
\hline & Employees & 7 & 12.73 & 10 & 17 \\
\hline & Labor & 2 & 3.64 & 1 & 2 \\
\hline & Farmers & 0 & 0 & 4 & 7 \\
\hline & Teacher & 2 & 3.64 & 0 & 0 \\
\hline & Traders & 3 & 5.45 & 10 & 17 \\
\hline & Retired & 2 & 3.64 & 0 & 0 \\
\hline \multirow{5}{*}{$\begin{array}{l}\text { Length of } \\
\text { diagnosed } \\
\text { hypertension } \\
\text { (years) }\end{array}$} & $<1$ & 5 & 9.09 & 10 & 16 \\
\hline & $1-5$ & 35 & 63.64 & 40 & 67 \\
\hline & $6-10$ & 11 & 20 & 7 & 12 \\
\hline & $11-20$ & 3 & 5.45 & 1 & 2 \\
\hline & $>20$ & 1 & 1.82 & 2 & 3 \\
\hline \multirow{2}{*}{$\begin{array}{l}\text { Types of } \\
\text { treatment }\end{array}$} & Monotherapy & 45 & 82 & 57 & 95 \\
\hline & Combination therapy & 10 & 18 & 3 & 5 \\
\hline
\end{tabular}




\section{STRADA Jurnal Ilmiah Kesehatan}

DOI: $10.30994 /$ sjik.v9i2.395

ISSN: 2252-3847 (print); 2614-350X (online)

Vol.9 No.2 November 2020 Page.831-839

The Successful Treatment of Blood Pressure in Hypertension Patients

The successful treatment in hypertension patients showed an increase in the quality life of the patients and the avoidance of complications.

Table 2. Data on the Success Category of Systolic Blood Pressure in Hypertension Patients

\begin{tabular}{|c|c|c|c|c|c|c|c|c|}
\hline \multirow[t]{3}{*}{ Group } & \multirow{2}{*}{\multicolumn{4}{|c|}{$\begin{array}{c}\text { Pre } \\
\text { Systolic } \\
\text { Total (\%) }\end{array}$}} & \multirow{2}{*}{\multicolumn{4}{|c|}{$\begin{array}{c}\text { Post } \\
\text { Systolic } \\
\text { Total (\%) }\end{array}$}} \\
\hline & & & & & & & & \\
\hline & Normal & $\begin{array}{c}\text { Pre } \\
\text { Hypertension }\end{array}$ & $\begin{array}{l}\text { Hypertension } \\
\text { Stage 1 }\end{array}$ & $\begin{array}{c}\text { Hypertension } \\
\text { Stage } 2 \\
\end{array}$ & Normal & $\begin{array}{c}\text { Pre } \\
\text { Hypertension }\end{array}$ & $\begin{array}{l}\text { Hypertension } \\
\text { Stage } 1\end{array}$ & $\begin{array}{c}\text { Hypertension } \\
\text { Stage } 2 \\
\end{array}$ \\
\hline Control & $4(7.3)$ & $24(43.6)$ & $21(38.2)$ & $6(10.9)$ & 7 (12.7) & $29(52.7)$ & $19(34.5)$ & $0(0)$ \\
\hline Intervention & $4(6.7)$ & $17(28.3)$ & $27(45)$ & $12(20)$ & $4(6.7)$ & $30(50)$ & $22(36.7)$ & $4(6.7)$ \\
\hline
\end{tabular}

Table 3. Data on the Success Category of Diastolic Blood Pressure in Hypertension Patients

\begin{tabular}{|c|c|c|c|c|c|c|c|c|}
\hline \multirow[t]{3}{*}{ Group } & \multirow{2}{*}{\multicolumn{4}{|c|}{$\begin{array}{c}\text { Pre } \\
\text { Diastolic } \\
\text { Total (\%) }\end{array}$}} & \multirow{2}{*}{\multicolumn{4}{|c|}{$\begin{array}{c}\text { Post } \\
\text { Diastolic } \\
\text { Total (\%) }\end{array}$}} \\
\hline & & & & & & & & \\
\hline & Normal & $\begin{array}{l}\text { Pre } \\
\text { Hypertension }\end{array}$ & $\begin{array}{c}\text { Hypertension } \\
\text { Stage 1 }\end{array}$ & $\begin{array}{c}\text { Hypertension } \\
\text { Stage } 2 \\
\end{array}$ & Normal & $\begin{array}{l}\text { Pre } \\
\text { Hypertension }\end{array}$ & $\begin{array}{c}\text { Hypertension } \\
\text { Stage } 1\end{array}$ & $\begin{array}{c}\text { Hypertension } \\
\text { Stage } 2 \\
\end{array}$ \\
\hline Control & $3(5.5)$ & $36(65.5)$ & $11(20)$ & $5(9.1)$ & $6(10.9)$ & $42(76.4)$ & $7(12.7)$ & $0(0)$ \\
\hline Intervention & $\begin{array}{r}13 \\
(21.7) \\
\end{array}$ & $22(36.7)$ & $19(31.7)$ & $6(10)$ & $21(35)$ & $21(35)$ & $13(21.7)$ & $5(8.3)$ \\
\hline
\end{tabular}

Table 4. Statistical Analysis of the Effects of Self Reminder Card on the Successful of Systolic Blood Pressure in Hypertension Patients

\begin{tabular}{|l|c|}
\hline \multicolumn{1}{|c|}{ Statistical Analysis } & p value \\
\hline Intervention Group pre post (Wilcoxon Signed Rank test) & 0.009 \\
\hline Control group vs intervention group (Mann-Whitney test) & 0.009 \\
\hline
\end{tabular}

Table 5. Statistical Analysis of the Effect of Self Reminder Card on the Successful of Diastolic Blood Pressure in Hypertensive Patients

\begin{tabular}{|l|c|}
\hline \multicolumn{1}{|c|}{ Statistical Analysis } & p value \\
\hline Intervention Group pre post (Wilcoxon Signed Rank test) & 0.016 \\
\hline Control group vs intervention group (Mann-Whitney test) & 0.935 \\
\hline
\end{tabular}

\section{DISCUSSION}

The sample data on this study was 115 patients by considering inclusion and exclusion research criteria, which were divided into 2 , namely control groups (55 patients) and interventions (60 patients) given self-reminder card. The data presented in table 1. 


\section{STRADA Jurnal Ilmiah Kesehatan}

DOI: $10.30994 /$ sjik.v9i2.395

ISSN: 2252-3847 (print); 2614-350X (online)

Vol.9 No.2 November 2020 Page.831-839

The successful of treatment in hypertension patients was influenced by several factors, namely the patient's activeness and willingness to see a doctor according to a determined schedule and adherence to take antihypertensive drugs. The factors that influenced the adherence consisted of age, gender, ethnicity, employment status and education. Based on the data on the characteristics of the study sample, the sex in the control and intervention groups was dominated by women. In general, the number of men suffered from hypertension bigger than the number of women suffered hypertension, with a ratio of about $2.29 \%$ for an increase in systolic blood pressure. Men tended to see signs of hypertension in their late thirties. Men assumed to have a lifestyle that tended to increase blood pressure compared to women. However, after entering menopause, the prevalence of hypertension in women increased. Women had a higher risk of developing hypertension. The production of the hormone estrogen decreased at menopause, women lost its beneficial effects so that blood pressure increased (14).

The majority of diabetes mellitus patients in the control group were patients aged 60-69 years, while those in the intervention group were 5-59 years old. Hypertension increased in line with age, the older a person was, the regulation of calcium metabolism was disturbed. This caused a large amount of calcium to circulate with the bloodstream. As a result, the blood became solid and blood pressure increased. Calcium deposits on the walls of blood vessels caused the blood vessels (arteriosclerosis) became narrow. Blood flow became disrupted and triggered an increase in blood pressure (15) (16). Age over 40 years had a risk of developing hypertension. Increasing age caused the elasticity of the arteries decreased and the heart had to pump blood strongly, increased blood pressure (17).

For patient characteristics, in terms of education for the control and intervention groups, the majority of the last education was junior high school and senior high school. Education is an activity or learning process to develop or improve certain abilities so that educational goals can stand on their own (18). Respondents with higher education tended have a broader knowledge than respondents with lower levels of education. Sugiharto et al (2003) also stated that the level of education can affect a person's ability and knowledge in implementing healthy living behaviors, especially preventing hypertension. The higher the level of education, the higher a person's ability to maintain a healthy lifestyle (19) .

If the characteristics of the research sample seen from the job aspects, the two sample groups in this study were dominated by patients who worked as housewives. This was in line with research which stated that respondents who did not work have a 1.42 times risk of developing hypertension because work was related to psychological effects on the work environment. (20). The psychological effects experienced were possibly in the form of stressful conditions. This was also in accordance with the theory that stress was able to increase peripheral blood vessels and cardiac output so that it stimulated sympathetic nerve activity. (21)

Characteristics of the study sample seen from the duration of being diagnosed with hypertension in the results of this study in the control and intervention groups were majority 1-5 years. The duration of hypertension had a relationship with the respondent's level of anxiety. Respondents, who were aware of the symptoms of hypertension felt worry and fear, so that it caused anxiety. The long process of hypertension treatment that did not show an end also increased the level of anxiety.(22)(23)

On the characteristics of the treatment obtained by patients was the majority of treatment with single therapy. This was in accordance with the research of Norman (2012) and Saepudin, et al (2013) who obtained the results that most respondents received a single antihypertensive drug.(24) 


\section{STRADA Jurnal Ilmiah Kesehatan}

DOI: $10.30994 /$ sjik.v9i2.395

ISSN: 2252-3847 (print); 2614-350X (online)

Vol.9 No.2 November 2020 Page.831-839

\section{Successful Treatment of Blood Pressure in Hypertensive Patients}

The successful treatment of hypertension patients showed an increase in the quality of life of the patient and the avoidance of complications. The successful treatment was influenced by the adherence, motivation, and family support. The successful of diabetes mellitus treatment was able to be increased by regulating diet, monitoring systolic and diastolic blood pressure (25)(26).

The results of data on table 2, the successful treatment of hypertension patients' blood pressure as shown in table 2 showed that the systolic blood pressure in the control group of pre 24 patients (43.6\%) and post 29 patients (52.7\%) in pre hypertension category. Diastolic blood pressure in the control group pre 36 patients $(65.5 \%)$ and post 42 patients $(76.4 \%)$ in the pre hypertension category so that the successful treatment of blood pressure in the control group did not change descriptively.

The results of data on table 3 , in the intervention group, the systolic blood pressure showed pre 27 patients (45\%) with the hypertension category stage 1 and post 30 patients (50\%) with the pre hypertension category. Diastolic blood pressure pre 22 patients was $36.3 \%$ in pre hypertension category and 21 patients was 35\% in pre hypertension category and 21 patients was $35 \%$ in the normal category. So descriptively the successful treatment of blood pressure in the intervention group showed a decrease in the hypertension category. Giving self-reminder cards to these patients has an impact on the successful treatment in reducing blood pressure in hypertension patients.

The results of the analysis were based on table 4 that the successful of systolic blood pressure in patients pre and post the intervention group with a $p$ value of 0.009 indicated that there was a significant difference between the systolic blood pressure pre and post study. Then the successful of the therapy was analyzed based on the two groups using the Mann Whitney test with a $\mathrm{p}$ value of 0.009 so it showed that there was an effect of the selfreminder card on the successful of patient therapy in reducing systolic blood pressure of hypertension patients.

The results of the analysis were based on table 5 that the successful of diastolic blood pressure in patients with pre and post intervention group with a $\mathrm{p}$ value of 0.016 indicated that there was no significant difference between the diastolic blood pressure pre and post study. Then, the successful of the therapy was analyzed based on the two groups using the Mann Whitney test with a $\mathrm{p}$ value of 0.935 so it showed that there was no effect of the self-reminder card on the successful of patient therapy in reducing diastolic blood pressure in hypertension patients.

\section{CONCLUSION}

Self-reminder card given to hypertension patients proven to be effectively effected in the successful treatment of systolic blood pressure, yet it showed ineffective in the successful treatment of diastolic blood pressure of hypertension patients.

\section{ACKNOWLEDGMENT}

Thank you to the Simlitabmas Ristekdikti Research Scheme for Beginner Lecturers, Funding in 2020.

\section{CONFLICT OF INTEREST}

There is no conflict of interest in this study 


\section{STRADA Jurnal Ilmiah Kesehatan}

DOI: $10.30994 /$ sjik.v9i2.395

ISSN: 2252-3847 (print); 2614-350X (online)

Vol.9 No.2 November 2020 Page.831-839

\section{REFERENCE}

1. Radermacher J. Hypertension. Gefasschirurgie. 2020.

2. Kemenkes RI. Hasil Utama Riset Kesehatan Dasar 2018. Kementrian Kesehat Republik Indones. 2018;

3. WHO. Global Health Risks: Mortality and burden of disease attributable to selected major risks. Bull World Health Organ. 2009;

4. Kemenkes RI. Hipertensi. Infodatin Pus dan Inf Kementeri Kesehat RI. 2014;

5. Vollmer WM, Owen-Smith AA, Tom JO, Laws R, Ditmer DG, Smith DH, et al. Improving Adherence to Cardiovascular Disease Medications With Information Technology - See more at: http://www.ajmc.com/journals/issue/2014/2014-11-vol20sp/improving-adherence-to-cardiovascular-disease-medications-with-informationtechnology\#sthash.jGHW. Am J Manag Care. 2014;

6. Dinas Kesehatan Republik Indonesia. Riset Kesehatan Dasar. Diabetes Mellit. 2013;87-90.

7. Ozoemena EL, Iweama CN, Agbaje OS, Umoke PCI, Ene OC, Ofili PC, et al. Effects of a health education intervention on hypertension-related knowledge, prevention and self-care practices in Nigerian retirees: A quasi-experimental study. Arch Public Heal. 2019;77(1):1-16.

8. Krousel-Wood M, Hyre A, Muntner P, Morisky D. Methods to improve medication adherence in patients with hypertension: Current status and future directions. Current Opinion in Cardiology. 2005.

9. Direktorat Bina Farmasi Komunitas dan Klinik DBK dan, Kesehatan A. Pedoman Pelayanan Kefarmasian Di Rumah. J Chem Inf Model. 2019;

10. Baker R, Farooqi A, Tait C, Walsh S. Randomised controlled trial of reminders to enhance the impact of audit in general practice on management of patients who use benzodiazepines. Qual Saf Heal Care. 1997;

11. Costa FA, Guerreiro JP, Melo MN, Miranda A da C, Martins AP, Garçāo J, et al. Effect of reminder cards on compliance with antihypertensive medication. Int J Pharm Pract. 2005;

12. Hemmati Maslakpak M, Safaie M. Effect of Reminder Cards on Adherence to Treatment in Patients with Uncontrolled Hypertension. Iran J Nurs Res. 2016 Dec 10;11(5):26-31.

13. Litbang Kemkes. Riset Kesehatan Dasar (RISKESDAS) 2013. Laporan Nasional 2013. 2013.

14. Moradi-Lakeh M, El Bcheraoui C, Daoud F, Tuffaha M, Wilson S, Al Saeedi M, et al. Medication use for chronic health conditions among adults in Saudi Arabia: Findings from a national household survey. Pharmacoepidemiol Drug Saf. 2016;

15. Al Hayek AA, Robert AA, Al Saeed A, Alzaid AA, Al Sabaan FS. Factors associated with health-related quality of life among saudi patients with type 2 diabetes mellitus: A cross-sectional survey. Diabetes Metab J. 2014;

16. Fandinata SS. Perubahan Kadar Protein dalam Urin terhadap Penggunaan Obat Antihipertensi (Valsartan) pada Pasien Nefropati Change of Urinary Protein Levels due to Antihypertention ( Valsartan ) Usage in Nephrophaty Patients. J Pharm Sci. 2019;4(1):1-6.

17. Williams B, Mancia G, Spiering W, Rosei EA, Azizi M, Burnier M, et al. 2018 practice guidelines for the management of arterial hypertension of the European society of cardiology and the European society of hypertension ESC/ESH task force for the management of arterial hypertension. Journal of Hypertension. 2018. 


\section{STRADA Jurnal Ilmiah Kesehatan}

DOI: $10.30994 /$ sjik.v9i2.395

ISSN: 2252-3847 (print); 2614-350X (online)

Vol.9 No.2 November 2020 Page.831-839

18. Notoatmodjo S. Promosi Kesehatan dan Perilaku Kesehatan (edisi revisi 2012). Jakarta: rineka cipta. 2012.

19. Sugiharto A. Faktor-Faktor Risiko Hipertensi Grade Ii. Tesis. 2007.

20. ANALISIS FAKTOR YANG MEMENGARUHI KEPATUHAN PENGGUNAAN OBAT PASIEN DIABETES MELITUS TIPE 2. Anal Fakt YANG MEMENGARUHI KEPATUHAN Pengguna OBAT PASIEN DIABETES MELITUS TIPE 2. 2016;

21. Wu K, Lee HJ, Desai MA. Risk factors for early onset elevated intraocular pressure after pterygium surgery. Clin Ophthalmol. 2018;

22. Fandinata SS, Darmawan R, Surabaya AF. BARU TERDIAGNOSA DAN SUDAH LAMA TERDIAGNOSA PENYAKIT DIABETES MELITUS TIPE 2. 2020;6(1):706.

23. Tipe M, Baru Y, Dan T, Lama S, Argalita P, Utami T, et al. ( The Differences Of Medication Adherence Between Newly and Long Been Diagnosed Patients With Diabetes Mellitus Type 2 ) obat DM telah diuji valid dan reliabilitas . 475.

24. Anggara FHD, Prayitno N. Faktor-Faktor Yang Berhubungan Dengan Tekanan Darah di Puskesmas Telaga Murni Cikarang Barat Tahun 2012. J Ilm Kesehat. 2013;

25. AlShareef SM, AlWabel AA, AlKhathlan MA, AlKhazi AA, AlMaarik AK, AlGarni AM, et al. Glycemic Control in Diabetic Patients in Saudi Arabia: The Role of Knowledge and Self-Management - A Cross-Sectional Study. Glob J Health Sci. 2017;

26. Fandinata SS, Darmawan R. Pengaruh Kepatuhan Minum Obat Oral Anti Diabetik Terhadap Kadar Gula Darah Pada Pasien Diabetes Mellitus Tipe II. 2020;10(1):23-31. 